\title{
Pusan 2001
}

\author{
By Ron Holloway
}

Spring 2002 Issue of KINEMA

\section{PUSAN INTERNATIONAL FILM FESTIVAL 2001}

Korean cinema officially came of age at the Sixth Pusan International Film Festival (9-17 November 2001) when all three international awards -- the New Currents Award, the FIPRESCI (International Critics) Award, and the NETPAC (Network for the Promotion of Asian Cinema) Award -- were given to Korean films over entries from other Asian countries. Among Pusan devotees, there had never been any doubt that Korean filmmakers commanded a front position in the ranks of Asian cinema. But when the awards were handed out on closing night in the brand new Busan Exhibition \& Convention Centre (BEXCO), the flagship venue for festival galas, the triple honours seemed all the more appropriate. It was a tip of the hat as well to Kim Dong-ho, the charismatic director of the Pusan International Film Festival, who had guided PIFF to its present status as the finest showcase of Asian cinema on the festival calendar.

\section{Korean Cinema Prevails}

When all was said and done, two Korean films in the New Currents section emerged as the front-runners: Song Il-gon's Kotsom (Flower Island) and Jeong Jae-eun's Goyangyi-rul Butakhae (Take Care of My Cat). In addition, two more films by recognized auteur directors in the Korean Panorama are also sure to surface this year at major festivals: Hur Jin-ho's Bomnarun Ganda (One Fine Spring Day) and Kim Ki-duk's Napun Namja (Bad Guy).

Although Song Il-gon's Flower Island had premiered a few months earlier at Venice in the Cinema of the Present section, it was also deemed the discovery of this year's PIFF. A spiritual film about faith, the human condition, and "a place never far away," this is the poignant story of three women, each with a painful past, who meet by chance on a mountain road in the dead of winter. Hearing that there's an off-shore refuge called Flower Island, where troubles vanish and a weary soul can rest, they decide to journey there. Hye-nae, a rape victim, has abandoned her new-born child in a toilet and wants to find her mother. Ok-nam, a prostitute, became what she is when forced to lower herself in order to buy her child a piano. Yoo-jin, a singer, has just been told she is dying of throat cancer and is saved from committing suicide by the other two women. Together they set out for the fabled island of wonders -- and along the way they find themselves.

"I hope this film will be a short requiem about the pain of sacrificed people," said Song Il-gon, who had studied cinema under documentarist Kazimierz Karabasz at the Polish Film School in Lodz. It was all of that, and more. It links with Song's short film The Picnic (Grand Jury Prize, Cannes 1999), in which he also sensitively treated death in a story of a family suicide. At 30 years young, Song Il-gon shows the promise of a talented auteur in the old of a Tarkovsky or Kielowski. Flower Island, shot with a digital camera and a small crew, received the New Currents Award, Pusan's top festival prize.

In Jeong Jae-eun's Take Care of My Cat the focus is on five girls who have just graduated from a trade school in Incheon, a seaport city connected to Seoul with a railway bridge. Though each dreams of finding a job and starting a new life, they like each other's company so much that they gather at regular intervals for parties and birthdays. When one receives a cat for a present, they all rejoice -- thus, it only seems right that when the trials of life prove too much for the first owner, the cat is passed on to the next, and then the next.

As it turns out, the passage to womanhood is painful for all, although each deserves more than she receives. One exhausts herself working as an all-around secretary for a large company in Seoul, another types manuscripts for a poet with infantile paralysis, a third spends her hours looking for work while carrying for her aged grandparents, and the Chinese twins know that their chances of advancement are slim in the first place because they stand on the lower rung of the social ladder. Slowly, but surely, the girls drift apart. Finally, with all options exhausted, two of them decide to leave Incheon together to find work elsewhere -and so they leave the cat with the Chinese twins. Take Care of My Cat, an international premiere at Pusan, won the NETPAC Award. 
Hur Jin-ho's One Fine Spring Day finds the director reunited with popular screen actress Lee Young Ae. Their previous film together, Christmas in August (1998), the story of a police woman in love with a photographer afflicted with a terminal illness that he tries to hide, was a hit at the Korean box office and on the international festival circuit, thus paving the way for coproduction support from Japan and Hong Kong on this project. As the bucolic title hints, One Fine Spring Day comes across as another quiet, moving, bittersweet, heart-rending love story, this time about a sound recording engineer hopelessly in love with an anchor-woman at a local TV station. One Fine Spring Day was already a commercial hit in Korea, Hong Kong, and Japan (it had competed at Tokyo) before the Pusan festival, where it won the FIPRESCI Award.

Often referred to as Korea's "cult director," due to his string of awards on the international festival circuit, Kim Ki-duk competed at Venice with The Isle (1999, NETPAC Award) and Address Unknown (2001), both critical statements on social conditions by a director with a conscience and a style to match. His Real Fiction (2000), an improvised piece of street theatre shot with a digital camera, was invited to compete at Moscow this past summer. To top this, word spread quickly at this year's Pusan festival that Kim's new film, Bad Guy, the story of a girl dragged into prostitution at the hands of a smalltime gangster, was being considered for the Berlinale. Bad Guy, a world premiere at Pusan, takes up where Kim's previous film, Birdcage Inn (1998), left off. Invited to participate in the Panorama section at the 1999 Berlinale, Birdcage Inn is the story of a girl who became a prostitute after having been raped by her father.

A half-dozen other Korean films also made an impact on critics and visiting festival directors at Pusan. Bae Chang-ho's The Last Witness, the opening night presentation in the brand new BEXCO all-purpose exhibition centre, commanded audience respect as a competent North-South Korean detective-thriller with its core theme set in the troubled past. Park Ki-yong's Camel(s), shot with a small digital camera, follows a non-communicative middle-aged couple on their rather agonizing route to a one-night stand. Kwak Kyungtaek's Friend, already the season's top box office hit before it was shown at Pusan, traces the paths of four friends from their youth to when they depart as adults, two to enter college and the other two to become gangsters. Song Hye-sung's Failan, another film set in the world of crime, is about a smalltime, good-hearted gangster who one day finds himself caught in the web of a quickie marriage. And Min Boung-hun's Let's Not Cry, shot in Turkmenistan by the filmmaker who had co-directed with Jamshed Usmanov the award-winning The Flight of the Bee (1998), is the droll story of a would-be musician who returns to his native village after piling up too many gambling debts in Moscow.

\section{Window on Asian Cinema}

Among the highlights of the Sixth Pusan International Film Festival was the sidebar program titled "Bangkok Express: Close Encounter with New Thai Films" in conjunction with the closing night gala presentation of MC Chatrichalerm Yukol's Suriyothai, a three-hour (shorter cinema version) national epic set in the 16th century that features 2,000 extras, 80 elephants, and 70 horses for the stupendous battle scenes.

Two new Chinese films had their international premieres at Pusan, both of which will surely appeal more to festival audiences than the authorities at home. In Mabel Cheung's Beijing Rocks (Hong Kong-China) we follow an illegal rock band as it tours the back roads of mainland China with motorcycles, a trailer, and makeshift camping gear. Always a step ahead of the police and usually in need of the amenities of life -money, food, pot -- they let the audience into what's going on by speaking directly into the camera. Along the way we learn why Road, the band leader, has left his village to seek a life with music, why Michael has run away from his tyrannical father in Hong Kong, and the wild and attractive Yang Ying is drawn to both Road and Michael for different reasons. Although Mabel Cheung, who studied cinema at New York University, has given Beijing Rocks an American road movie flair, the film sparkles when the focus is on today's Chinese rock music style -- and it particularly comes to life when the band breaks out with a rather unique rendition of the "International" on the soundtrack.

In Zhang Yimou's warming Happy Time (China), a straight-forward comédie humaine about a retiree in love with a fat woman, the rub comes when the old man opens a rendezvous trailer-house called "Happy Time" for passing lovers in order to raise the money he needs for the dowry. As it happens, however, he and his retired senior friends find themselves strapped with a young blind girl instead, who then wins their hearts with her unaffected ways and thus gives the old man back more love in return than he had ever desired or expected. Happy Time, about ordinary people leading conventional lives, links with Zhang's previous 
"community" films, Not One Less, 1998) and The Road Home, 2000), to form a kind of trilogy on the role of women in traditional Chinese society.

Asian films seen and awarded at Cannes were the main audience attractions in the Window on Asian Cinema section, particularly as many of these awarded films were having their Asian premieres at Pusan. Crowds turned out for the Mohsen Makhmalbaf's Kandahar (Iran-France), a timely film that is still causing waves and seems to take the pulse of world events more today than last May at Cannes, where it was given the Ecumenical Award. Other sellouts were Hou Hsiao-hsien's Millennium Mambo (Taiwan-France), with Hou serving on the New Currents jury, and Tsai Ming-liang's What Time Is It There? (TaiwanFrance), both award winners at Cannes (Du Tuu-chih received the Technical Prize for Sound). From Japan came Shohei Imamura's Warm Water under a Red Bridge (Japan-France), with Imamura present at Pusan Project Plan meetings to pitch his Shinjuku Cherry Blossom Fantasy project. From Central Asia came Darezhan Omirbaev's The Road (Kazakhstan-France) and Aktan Abdykalykov's The Chimp (KyrgyzstanFrance-Japan), both of which premiered in the Certain Regard at Cannes. And from India came Murali Nair's A Dog's Life (India-UK), another Certain Regard entry.

If there was one film that seemed to please everybody, audience and critics, then it was the Golden Lion winner at Venice: Mira Nair's Monsoon Wedding (India), an exhilarating comedy set in Delhi about a Punjabi family racing to wrap a wedding ceremony before the seasonal rains set in to wash it away. Equally at home in Manhattan, Kampala (Uganda), and New Delhi, Mira Nair (she's not related to Murali Nair) is a familiar name on the international scene. Educated at Harvard, she came to the feature film by way of street theatre and the documentary, applying the lessons she learned to Salaam Bombay (1988), awarded the Caméra d'Or at Cannes and honoured with an Oscar Nomination. Shot around Bombay's notorious Grant Street Station, with nonprofessional children from the neighbourhood in the lead roles, Salaam Bombay came across as a fiction-documentary cut from life, a film made possible from street-theatre workshops and aided by the advantages of a handheld camera.

Much the same can be said of Monsoon Wedding. "It's a joining together of theatre and workshops," said Mira Nair in a Venice interview, "to capture the extraordinariness of ordinary life." Shooting on a tight 30day schedule and contending daily with an oppressive heat, both of which added to the hurry-up atmosphere in this typical Punjabi-Indian tale, she sketches with her handheld camera a wedding party brimmed with flowers, costumes, folk music, sweets, and family confessions that spill out onto the table to animate the scene.

"India is a fantastic place," said Nair in an interview, "because we have opened our doors to people from all over the world. We borrow, steal, absorb, assimilate -- then somehow mix it all together to make something typically Indian." Even the film's dialogue is a spoken mix of English, Hindi, and Punjabi. As for the dress worn in the film, Indian traditional costumes clash with today's jeans and Gucci styles. "We wanted to capture a time in Indian society."

Much the same can be said about the Pusan International Film Festival. At no other festival on the calendar can the visitor from abroad assimilate moments of time in Asian society and culture as lived today.

\section{References}

AWARDS:

New Currents Award

Kotsom (Flower Island, Korea), Song Il-gon

Special Mention: Goyangyi-rul Butakhae (Take Care of My Cat, Korea), Jeong Jae-eun

FIPRESCI (International Critics) Award

Kotsom (Flower Island, Korea), Song Il-gon

Special Mention: Bomnarun Ganda (One Fine Spring Day, Korea-Japan-Hong Kong), Hur Jun-ho 
NETPAC (Network for Promotion of Asian Cinema) Award

Goyangyi-rul Butakhae (Take Care of My Cat, Korea), Jeong Jae-eun

Special Mentions: Waikiki Brothers (Korea), Yim Soon-rhe, and Napun Namja (Bad Guy, Korea), Kim Ki-duk

Sonje Award (Best Korean Short Film)

Siam -- Hard Romance, Kim Jeong-gu

Woonpa Award (Best Korean Documentary)

Farewell, Hwang Yun

PSB (Pusan System of Broadcasting) Audience Award

Kotsom (Flower Island, Korea), Song Il-gon

Korean Cinema Award

Eva Zaoralová, Artistic Director, Karlovy Vary International Film Festival

\section{Author Information}

Ron HOLLOWAY (1933-2009) was an American critic, film historian, filmmaker and correspondent who adopted Europe as his home in the early fifties and spent much of his life in Berlin. He was an expert on the study of German cinema and against all odds produced, with his wife Dorothea, the journal German Film, keeping us up-to-date with the work of directors, producers and writers and the showing of German films around the world.

In 2007, Ron Holloway and his wife were awarded the Berlinale Camera Award. Ron also received the Bundesverdienstkreuz (German Cross of Merit), Polish Rings, Cannes Gold Medaille, the American Cinema Foundation Award, the Diploma for Support of Russian Cinema and an honorary award from the German Film Critics' Association.

Ron was also a valued contributor to Kinema for the past fifteen years. 